\title{
Pengaruh Layanan Bimbingan Kelompok Teknik Modeling Terhadap Minat Wirausaha pada Siswa
}

\author{
Renal Ismudya, Bambang Susanto, Muhammad Arief Maulana
}

Program Studi Bimbingan dan Konseling, Universitas Veteran Bangun Nusantara Email: ismudyarenal@yahoo.com

\begin{tabular}{|c|c|}
\hline Article Info & Abstrak \\
\hline $\begin{array}{l}\text { Available online } \\
31.12 .2019\end{array}$ & 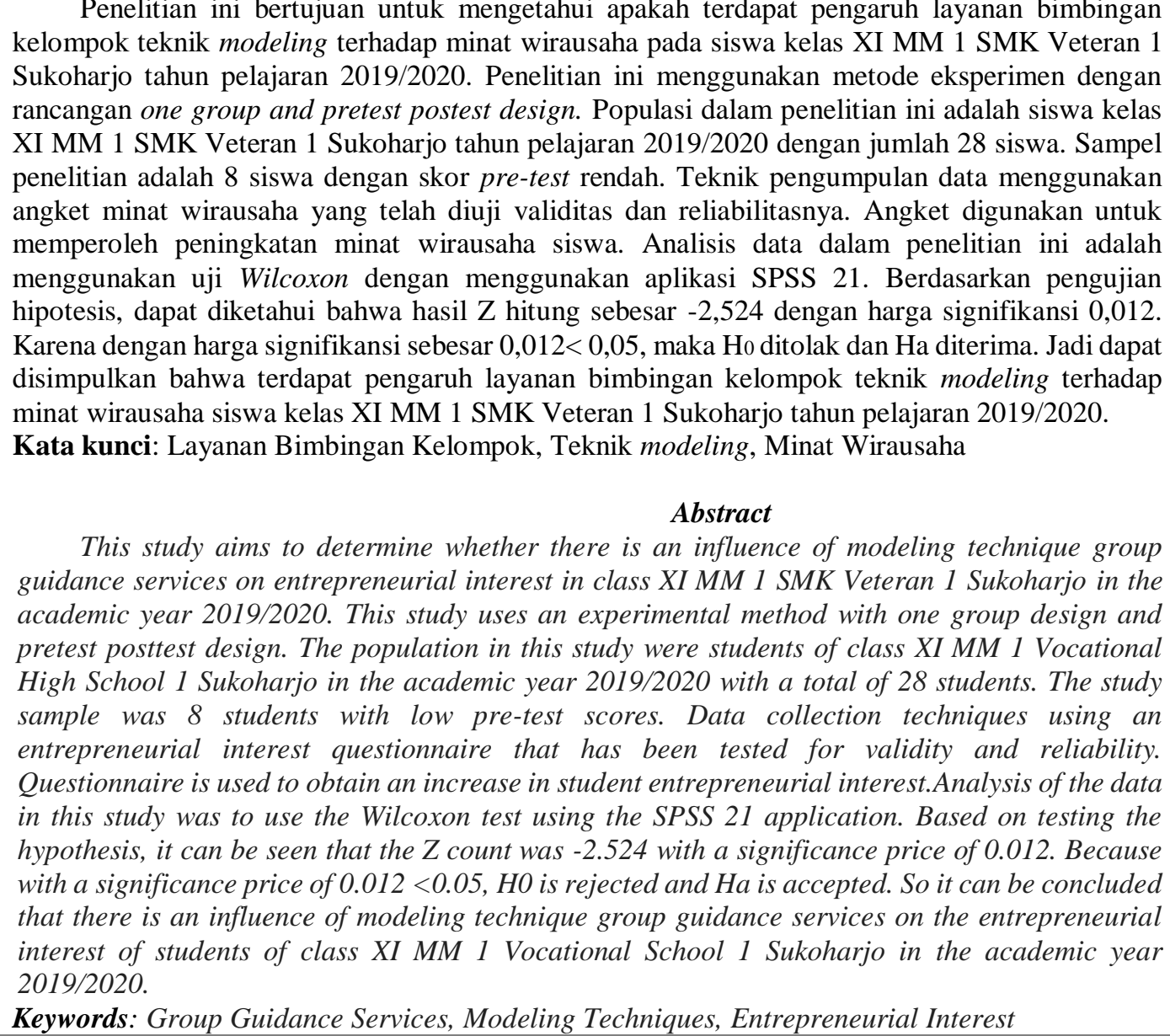 \\
\hline
\end{tabular}

\section{PENDAHULUAN}

Lulusan SMK diharapkan siap bekerja pada bidang pekerjaan yang sesuai dengan jurusan yang diambil, meskipun dalam kenyataan tidak semua lulusan SMK dapat langsung bekerja. Hal ini dapat dilakukan dengan mengembangkan keterampilan kewirausahaan untuk membekali peserta didik memiliki keterampilan yang mengarah pada pembentukan sikap kerja mandiri, berani mengambil resiko, kreatif dan inovatif. Mengingat kondisi ekonomi sedang lemah serta sulit mencari pekerjaan disektor pemerintahan dan swasta yang membutuhkan berbagai persyaratan melalui jenjang pendidikan, maka situasi tersebut menimbulkan minat bagi orang-orang untuk mencari atau membentuk usaha pribadi melalui ide dan keterampilan yang dimiliki untuk menjadi seorang wirausahawan. 
Minat wirausaha sangat dibutuhkan untuk mendongkrak jumlah wirausahawan di Indonesia sehingga mengurangi tingkat pengangguran. Menurut McClelland dalam Sahade (2016: 57) untuk menjadi negara yang makmur, suatu negara harus memiliki minimum $2 \%$ wirausahawan dari total penduduknya. Dari jumlah penduduk Indonesia yang mencapai 240 juta jiwa, baru sekitar 400 ribu yang memilih sebagai pengusaha, atau hanya $0,18 \%$. Jumlah itu lebih rendah dibandingkan dengan wirausaha di beberapa negara luar yang tingkat pertumbuhan ekonominya tinggi, seperti Amerika Serikat yang mencapai 11\%, Jepang 11\%, China 10\%, Singapura 7\%, dan Malaysia 3\%. Dengan adanya minat wirausaha, masyarakat dan khususnya siswa-siswi tamatan sekolah menengah akan tertarik untuk terjun langsung ke dunia wirausaha sehingga mampu mengurangi jumlah pengangguran dan dapat menambah lapangan pekerjaan.

Berdasarkan hasil observasi yang dilakukan saat Program Praktek Lapangan (PPL) di SMK Veteran 1 Sukoharjo, mayoritas peserta didik masih ragu untuk berwirausaha, mereka beralasan belum mempunyai cukup modal dan keterampilan untuk membuka usaha sendiri serta masih rendahnya minat peserta didik untuk memulai suatu usaha baru. Dengan adanya peran penting dan penyebab yang timbul dari uraian di atas maka diharapkan minat berwirausaha dapat ditingkatkan sehingga peserta didik dapat menumbuhkan semangat berwirausaha, menambah wawasan peserta didik mengenai dunia wirausaha serta dapat memotivasi peserta didik untuk ikut dalam dunia wirausaha, dan menjadikan mereka sebagai wirausahawan yang tangguh sehingga mereka mampu berkontribusi untuk meningkatkan taraf perekonomian negara Indonesia.

Melalui bimbingan kelompok diharapkan semua anggota kelompok dapat membina dan mengembangkan sikap bertanggung jawab, kepercayaan diri sendiri sertakemampuan untuk pengarahan dan penguasaan diri sehingga peserta didik dapat memecahkan masalah secara mandiri, pengembangan diri menjadi lebih luas, siswa dapat berperan aktif dalam berpendapat. Menurut Hallen (2005: 80) layanan bimbingan kelompok yaitu, layanan bimbingan dan konseling yang memungkinkan sejumlah peserta didik secara bersama-sama melalui dinamika kelompok memperoleh berbagai bahan dari narasumber tertentu (terutama dari guru pembimbing). Secara bersama-sama membahas pokok bahasan (topik) tertentu yang berguna untuk menunjang pemahaman dan kehidupannya sehari-hari dan atau untuk perkembangan dirinya baik sebagai individu maupun sebagai individu maupun sebagai pelajar, dan untuk pertimbangan dalam pengambilan keputusan dan atau tindakan tertentu. Menurut Nanda (2019: 48) layanan bimbingan kelompok adalah untuk membantu memecahkan masalah-masalah umum yang sedang dihadapi siswa secara mandiri, melatih siswa dalam mengembangkan kemampuan bersosialisasi serta meningkatkan kemampuan berkomunikasi verbal dan non-verbal, sehingga siswa mampu berinteraksi dengan baik, mengemukakan pendapatnya sendiri dan tidak sekedar mengikuti 
pendapat orang lain. Dalam hal ini untuk menumbuhkan minat wirausaha siswa, dilatarbelakangi oleh pemahaman bahwa bimbingan kelompok akan menciptakan interaksi yang positif diantara siswa untuk saling bertukar pendapat dan argumentasi. Didalam dinamika kelompok yang terjadi, terdapat proses interaksi antara dua atau lebih individu yang terlihat saling tukar menukar pengalaman dan informasi mengenai dunia wirausaha, kemudian akan muncul motivasi dan ketertarikan untuk berwirausaha.

Salah satu teknik yang dapat digunakan untuk meningkatkan minat berwirausaha yaitu melalui teknik modeling. Menurut Komalasari (2011: 176) menyebutkan bahwa modeling merupakan proses belajar melalui observasi dengan menambahkan atau mengurangi tingkah laku yang teramati, menggeneralisir berbagai pengamatan sekaligus melibatkan proses kognitif. Maka dapat disimpulkan bahwa modeling adalah proses belajar melalui orang lain sebagai model yang memiliki peran sebagai perangsang pikiran, sikap, dan tingkah laku. Keunggulan pelaksanaan layanan bimbingan kelompok teknik modeling dapat terjadi suatu interaksi timbal balik antara guru bimbingan dan konseling sebagai pemimpin kelompok dan siswa sebagai anggota kelompok. Dalam Penelitian ini pemimpin kelompok menyajikan model simbolis dalam bentuk media visual yang menjelaskan tokoh yang sudah menekuni dunia wirausaha, dengan memberikan pengalamanpengalaman dan informasi mengenai keterampilan berwirausaha yang dimillikinya. Dalam suasana tersebut, masing-masing siswa dapat memanfaatkan semua informasi tentang wirausaha sehingga timbul reaksi dari siswa lainnya untuk pengembangan minat wirausaha.

\section{METODE PENELITIAN}

Metode penelitian yang digunakan dalam penelitian ini adalah metode penelitian eksperimen. Menurut Sugiyono (2018: 72), Penelitian eksperimen merupakan suatu metode penelitian yang digunakan untuk mencari pengaruh perlakuan tertentu terhadap yang lain dalam kondisi yang dikendalikan. Penelitian menggunakan desain penelitian pre-experimental design. Menurut Sugiyono (2018: 114-115) pre-experimental design belum merupakan eksperimen secara keseluruhan, karena masih terdapat variabel luar yang berpengaruh terhadap terbentuknya variabel dependen. Bentuk pre-experimental design yang digunakan yaitu one group and pretest posttest design. Metode one group and pretest posttest design adalah satu kelompok tes diberikan satu perlakuan yang sama sebelum dan sesudah mendapatkan perlakuan tertentu. Dalam penelitian ini perlakuan yang diberikan adalah layanan bimbingan kelompok teknik modeling karena diduga layanan bimbingan kelompok teknik modeling (X) dapat mempengaruhi minat wirausaha siswa (Y). 
Sampel dalam penelitian ini mengambil sebagian sampel satu kelas yaitu XI MM 1 (Multimedia), yang selanjutnya diambil siswa dengan minat wirausaha yang rendah berdasarkan penyebaran angket yang disusun peneliti. Teknik purposive sampling, dengan menggunakan pertimbangan tertentu ini yaitu mencari siswa yang memiliki minat wirausaha yang kurang. Penelitian ini menggunakan teknik pengumpulan data berupa angket minat wirausaha. Angket minat wirausaha ini digunakan untuk mengetahui tinggi atau rendahnya minat wirausaha peserta didik. Penggunaan angket minat wirausaha ini dilakukan dengan cara memberi seperangkat pernyataan tertulis kepada responden untuk dijawabnya.Validitas instrument menggunakan rumus Product Moment, sedangkan reliabilitas menggunakan rumus Spearman Brown. Uji Hipotesis dengan melakukan uji beda berbantuan statistik nonparametris Wilcoxon.

\section{PEMBAHASAN}

\section{Kondisi Awal Minat Wirausaha}

Dari pre-test tersebut maka peneliti mengambil subyek penelitian sebanyak beberapa siswa. Pemilihan ini dilakukan dengan cara memilih subyek dengan perolehan nilai pre-test yang sangat rendah. Hasil pre-tes beberapa siswa yang dijadikan sampel penelitian sebagai berikut:

Tabel 1. Hasil Skor

\section{Pre-test Responden}

\begin{tabular}{|c|c||c|c|c|}
\hline No & Nama & Skor & Presentase (\%) & Kategori \\
\hline 1. & AWM & 106 & 46 & Rendah \\
\hline 2. & AE & 114 & 50 & Rendah \\
\hline 3. & DRA & 112 & 49 & Rendah \\
\hline 4. & FFK & 104 & 45 & Rendah \\
\hline 5. & KMD & 108 & 47 & Rendah \\
\hline 6. & NFF & 107 & 47 & Rendah \\
\hline 7. & WNA & 105 & 46 & Rendah \\
\hline 8. & ZS & 102 & 44 & Rendah \\
\hline & Rata-rata & 108 & 47 & Rendah \\
\hline
\end{tabular}

Kondisi awal minat wirausaha tergolong rendah, hal ini sesuai dengan fakta di sekolah. Siswa belum tertarik untuk berwirausaha, minat wirausaha siswa juga belum nampak. Peneliti berasumsi bahwa siswa perlu menumbuhkan minat wirausaha sebagai alternatif pilihan setelah lulus. 
Keseluruhan sampel penelitian akan diberikan perlakuan yaitu bimbingan kelompok teknik modeling.

\section{Kondisi Akhir Minat Wirausaha}

Layanan bimbingan kelompok teknik modeling diikuti oleh semua sampel penelitian. Terjadi peningkatan skor presentase minat wirausaha pada seluruh sampel. Berikut distribusi presentase post- test sampel penelitian:

Tabel 4.9

Hasil Skor Post-test Responden

\begin{tabular}{|c|c|c|c|c|}
\hline NO & Nama & Skor & Presentase(\%) & Kategori \\
\hline 1. & AWM & 186 & 80 & Tinggi \\
\hline 2. & AE & 171 & 74 & Tinggi \\
\hline 3 & DRA & 173 & 75 & Tinggi \\
\hline 4. & FFK & 167 & 73 & Tinggi \\
\hline 5. & KMD & 182 & 79 & Tinggi \\
\hline 6. & NFF & 181 & 79 & Tinggi \\
\hline 7. & WNA & 180 & 78 & Tinggi \\
\hline 8. & ZS & 178 & 77 & Tinggi \\
\hline \multicolumn{2}{|r|}{ Rata-rata } & 177 & 77 & Tinggi \\
\hline
\end{tabular}

Berdasarkan hasil perhitungan data berupa analisis deskrptif presentase sebelum dan setelah diberikan layanan bimbingan kelompok dengan teknik modeling serta hasil pengamatan selama proses pemberian perlakuan, menunjukan bahwa presentase minat wirausaha siswa lebih tinggi setelah diberikan perlakuan dari pada sebelum diberikan perlakuan dengan rata-rata peningkatan $31 \%$. Minat wirausaha siswa setelah diberikan perlakuan berupa layanan bimbingan kelompok dengan teknik modeling berbeda antara satu dengan yang lainnya. Dari delapan siswa yang mendapatkan perlakuan diperoleh data dengan tingkat minat wirausaha yang tinggi. Meskipun berada dalam kategori yang sama yaitu tinggi, namun dilihat pada hasil presentase minat wirausaha siswa setiap siswa menunjukan perbedaan presentase antara satu siswa dengan siswa yang lainnya. Hanya saja terdapat kesamaan peningkatan antara sebelum dan setelah diberikan perlakuan, yaitu dua siswa dengan peningkatan dikisaran 33\% (AWM dan ZS) dan tiga siswa dengan peningkatan dikisaran 32\% (KMD, NFF dan WNA) sisanya dengan peningkatan 27\% (FFK), 26\% (DRA), 25\% (AE). 
Apabila ditelaah lebih jauh, peningkatan paling tinggi setelah mendapatkan perlakuan dialami oleh dua siswa yaitu AWM dan ZS. Hal ini dikarenakan dari awal pertemuan siswa menunjukan sikap semangat dan sungguh-sungguh dalam mengikuti kegiatan yang mengindikasikan bahwa siswa memiliki minat wirausaha yang tinggi dalam dirinya untuk menjadi lebih baik. Peningkatan tertinggi kedua dialami tiga siswa yaitu KMD, NFF dan WNA dimana siswa juga menunjukan kesungguhan dalam mengikuti kegiatan serta ketiga siswa tersebut memiliki sikap keterbukaan dalam berpendapat sehingga siswa lebih mudah untuk berubah ke arah yang lebih baik. Peningkatan tertinggi ketiga yaitu FFK. Hal ini dikarenakan siswa dalam mengikuti kegiataan lebih cenderung hanya menikmati proses pemberian perlakuan. Peningkatan yang selanjutnya terjadi pada DRA dengan kisaran 26\%. Selama kegiatan layanan DRA cenderung pasif dan hanya sesekali terlihat aktif. Adapun peningkatan terendah dialami satu siswa yaitu AE. Hal ini dikarenakan siswa cenderung tertutup, pendiam dan jarang mengemukakan pendapatnya. Berdasarkan penjelasan tersebut, dapat disimpulkan bahwa perbedaan presentase minat wirausaha setiap siswa setelah mendapatkan perlakuan dipengaruhi oleh beberapa faktor diantaranya, perbedaan minat dan motivasi dalam berwirausaha, kemampuan menerima dan memahami informasi dan tipe kepribadian yang berbeda antara satu siswa dengan yang lainnya.

Menurut Bandura dalam Gunarsa (2007: 221) manfaat dari teknik modeling adalah: a) Pengambilan respon atau keterampilan baru dan diperlihatkan dalam perilakunya setelah memadukan apa yang diperoleh dari pengamatannya dengan perilaku baru, b) Hilangnya respon takut setelah melihat model melakukan sesuatu hal yang selama ini menimbulkan rasa takut oleh individu, c) Pengambilan suatu respon dari respon-respon yang diperlihatkan oleh model yang memberikan jalan untuk ditiru.

Berdasarkan pendapat diatas, manfaat penggunaan layanan bimbingan kelompok teknik modeling dalam penelitian ini adalah membantu siswa mengatasi keraguan- keraguan yang muncul mengenai dunia wirausaha dengan cara menampilkan model seorang wirausahawan yang menginspirasi lewat pengalaman-pengalaman yang dimilikinya, kemudian siswa belajar dan merespon hal-hal baru yang didapatkannya sehingga berpengaruh terhadap minat wirausaha siswa.

Penelitian yang dilakukan Widiyawati (2014) yang berjudul " Pengaruh Layanan Bimbingan Kelompok Teknik Modeling Simbolis Terhadap Minat Kewirausahaan Bidang Tata Busana ”. Penelitian ini adalah untuk mengetahui pengaruh layanan bimbingan kelompok teknik modeling simbolis terhadap minat kewirausahaan bidang tata busana kelas XII jurusan busana butik. Penelitian menunjukkan terjadi peningkatan minat wirausaha siswa sangat besar setelah pemberian treatment. Siswa yang diberi treatment menunjukan peningkatan minat wirausaha dalam kategori tinggi. Hal itu memberikan pemahaman bahwa sebagian besar siswa yang pada awalnya belum 
memiliki minat wirausaha yang baik, namun setelah dilakukan tindakan bimbingan yang berikutnya para siswa sudah menunjukan tanda-tanda memiliki minat wirausaha yang baik. Perubahan perilaku tersebut juga dapat dilihat dari proses pengamatan selama pemberian perlakuan sebanyak tiga kali pertemuan. Minat wirausaha siswa yang awalnya tidak nampak, pertemuan demi pertemuan mulai terlihat sedikit demi sedikit hingga pada akhirnya dapat dikatakan baik setelah rangkaian proses pemberian perlakuan selesai.

\section{KESIMPULAN DAN SARAN}

\section{Kesimpulan}

Berdasarkan Hasil penelitian yang dilakukan dengan memberikan treatment berupa bimbingan kelompok teknik modeling, maka dapat disimpulkan bahwa bimbingan kelompok teknik modeling berpengaruh signifikan terhadap minat wirausaha siswa kelas XI MM 1 SMK Veteran 1 Sukoharjo Tahun Pelajaran 2019/2020. Hasil tersebut menunjukkan bahwa hipotesis yang telah diajukan peneliti dapat diterima dan terbukti kebenarannya. Kebenaran tersebut di dukung dengan adanya pengujian hipotesis menggunakan uji Wilcoxon. Hasil pengujian terhadap skor pres-test dan posttest diperoleh hasil Z hitung sebesar -2.524 dengan harga signifikansi sebesar 0.012. Karena dengan harga signifikansi sebesar $0.012<0.05$, maka Ho ditolak dan Ha diterima, dengan demikian terdapat perbedaan signifikan pada saat pre-test dan post-test.

\section{DAFTAR PUSTAKA}

Gunarsa. Singgih D. (2007). Konseling dalam psikologi terapi. Jakarta : Gunung Mulia. Hallen, A. (2005). Bimbingan Konseling. Ciputat: Quantum Teaching.

Ika Widiyawati. (2014). Pengaruh teknik modeling terhadap minat kewirausahaan bidang tata busana siswa SMK N 7 Purworejo. Jurnal bimbingan dan konseling 3 (4).Retrieved fromhttps://core.ac.uk/download/pdf/33510726.pdf

Komalasari.G.. Wahyuni.G. \& Karsih. (2011). Teori dan Teknik Konseling. Jakarta : Indeks.

Sugiyono. (2018). Metode Penelitian Kuantitatif . Bandung: Alfabeta.

Wibowo, NAK.,Maulana, MA \& Susanto, B. (2019). Pengaruh Layanan Bimbingan Kelompok Teknik Role Playing Terhadap Interaksi Sosial Pada Siswa. Jurnal Bimbingan

Konseling, 1(1). Retrieved from

http://journal.univetbantara.ac.id/index.php/Advice. 
Yusuf, M.A., dan Sahade. (2016). Pengetahuan Wirausaha dan Minat Berwirausaha Pada Siswa SMK. Makassar: Jurnal Fakultas Ekonomi Universitas Negeri Makassar. Retrieved from http://ojs.unm.ac.id/Insani/article/view/2687 